\title{
Disability-Friendly Public Means Through the Public Services Regulation: Realizing a Disability Friendly in Bandar Lampung City
}

\author{
Sri Sulastuti \\ Faculty of Law \\ Lampung University \\ Lampung, Indonesia \\ tutiunila@yahoo.co.id
}

\author{
Ricco Andreas* \\ Faculty of Law \\ Lampung University \\ Lampung, Indonesia \\ 0000-00003-3985-3302
}

\begin{abstract}
Disabled people must have equal opportunities in their efforts to develop themselves. The rights of people with disabilities are still considered a social problem, where new policies are social security, social assistance, and the improvement of social welfare. The right of people with disabilities to access public services is provided and facilitated by providing and facilitating access to public services. The right to public services should also be provided for people with disabilities. People with disabilities have the right to use public services without discrimination. Public service regulations must protect and fulfill the constitutional rights of persons with disabilities in obtaining public services. The state's obligation to respect, protect, and fulfill the rights of persons with disabilities is regulated in Article 42 of Law no. 391999 on human rights. Likewise, what must be done in the city of Bandar Lampung through the Public Service Regulations? The legal issues of this study identify and provide an affirmative form of government policy in realizing the principle of "The State of Law for Welfare" equal rights for persons with disabilities to obtain accessibility through public service regulations in the city of Bandar Lampung. Research Methodology Dogmatic legal research is conducted through a literature study that examines primarily primary legal materials in the form of legislation, conventions, or other legal documents, as well as research results, assessment results, and other references. This study aims to provide services and protection to people with disabilities. This protection can also be interpreted as an acknowledgment that discrimination based on disability is a violation of the dignity and values inherent in every person. In addition, the protection of persons with disabilities can also be interpreted as an effort to create an accessible environment and public facilities for equal opportunities for persons with disabilities to live independently and in society.
\end{abstract}

Keywords-Policy, Affirmative, Difabel

\section{INTRODUCTION}

The rights of people with disabilities are guaranteed in the constitution [1], especially in Chapter XA on Human Rights [2]. As an explicit right in the United States, action must be taken to fulfill these rights [3]. Following the mandate of the Constitution when it comes to human rights [4]. If it is included in the constitution, there will be two possibilities. The first is when the government does not realize these rights and the second is when the government realizes these rights [5]. The best way for the government to realize the constitutional rights of persons with disabilities is to provide good accessibility [6].

However, the fact is that the rights of persons with disabilities as constitutional rights are often ignored. The existence of people with disabilities is often eroded by the flow of normality. People with disabilities experience various forms of discrimination. This is evidenced by the lack of fulfillment of facilities [7] and access [8] of support for persons with disabilities in public places [9], soft or hard refusal when applying for jobs, refusal in the field of education such as there are still many schools and colleges that rejecting prospective students and students with disabilities because they are not able to accept the lessons given [10]. The perspective of the approach of persons with disabilities is often charity-based, not human rightsbased. this causes various problems for persons with disabilities [11]. This perspective has given rise to government policy products that make it impossible for people with disabilities to exist. People with disabilities often live in limitations, obstacles, difficulties, and the denial of the rights of people with disabilities. This condition makes people with disabilities an essential part of society, as a whole. Discrimination is allowed when the principle of equality is violated [12]. People with disabilities should be seen as people who have equal rights and opportunities to live prosperous and 
independent life [13]. The Bandar Lampung City Government should be involved in people's welfare efforts such as directly providing various forms of basic services [14] such as education [15] and other public services. But back to the reality, that there are so many obstacles, difficulties, restrictions, reductions, and even elimination of rights for persons with disabilities in fulfilling their rights. The right to education is a very important right for the continuation of other rights [16].

According to data from the Central Statistics Agency for the city of Bandar Lampung from 2014 to 2017, there were 23,345 people with disabilities, and especially for the city of Bandar Lampung itself, there were 1,150 people with disabilities. With the importance of equal rights between persons with disabilities and non-disabled persons and a large number of disabled people in Lampung Province, in 2013 the Governor of Lampung issued Lampung Provincial Regulation Number 10 of 2013 concerning Services and Fulfillment of the Rights of Persons with Disabilities.

The enactment of this Regional Regulation will realize independence and welfare for persons with disabilities by giving respect and equality of position, rights, obligations, and participation for persons with disabilities in all aspects of life and livelihood [17] and providing services to persons with disabilities in the fields of education, employment, social, see Article 3 paragraph 1 of the Regulation of the Minister of National Education Number 70 of 2009 concerning Inclusive Education for Students who Have Abnormalities and Have Potential Intelligence and/or special talents.

The lack of awareness of public services in Bandar Lampung city shows that the presence of regulations at the regional level that regulates the protection of people with disabilities has not made the Bandar Lampung City area a disability-friendly city. In 2009, the Ministry of National Education issued the Regulation of the Minister of National Education Number 70 of 2009 concerning Inclusive Education for Students with Disabilities and Potential Intelligence and/or special talents. Regulations at the regional level that regulate the protection of persons with disabilities have not made the city of Bandar Lampung a disability-friendly city.

The Minister of National Education Article 3 paragraph 1 No. 70 issued a regulation in 2009 concerning the education of students with disabilities and potential intelligence and/or special talents. The city of Bandar Lampung is not aware of its public services, which suggests that there are no regulations at the regional level that regulate the protection of people with disabilities.

Based on the explanation that has been described above, several problems will be discussed further:
- First, how is the affirmative form of government policy in realizing the principle of equal rights for people with disabilities to obtain access through the regulation of public services in Bandar Lampung?

- Second, how to fulfill the rights of persons with disabilities in Bandar Lampung with the model of "The State of Law for Welfare" as a Public Service for persons with disabilities.

This study uses a normative legal research method which is carried out with a literature study that examines primary legal materials and research results in the form of legislation, conventions, or other legal documents, as well as study results and other references.

\section{DISCUSSION RESULTS}

A. Affirmative Form Government policy in realizing the principle of equal rights for people with disabilities to obtain accessibility through regulation of public services in Bandar Lampung

TABLE I. NEGLECTED CONSTITUTIONAL RIGHTS OF PERSONS WITH DISABILITIES [18].

\begin{tabular}{|c|c|c|}
\hline $\begin{array}{c}\text { Rights Setting } \\
\text { Type }\end{array}$ & $\begin{array}{c}\text { Rights } \\
\text { Setting Type }\end{array}$ & $\begin{array}{c}\text { Das Sein on the } \\
\text { Implementation of } \\
\text { Norms }\end{array}$ \\
\hline $\begin{array}{l}\text { HaEducation } \\
\text { word }\end{array}$ & $\begin{array}{l}\text { Article } 28 \\
\text { Letters H and } \\
\text { I of the } 1945 \\
\text { Constitution } \\
\text { Law no. } \\
\text { 20/2003 on } \\
\text { the National } \\
\text { Education } \\
\text { System } \\
\text { Law no. } \\
23 / 2002 \\
\text { concerning } \\
\text { Child } \\
\text { Protection jo. } \\
\text { Law no. } \\
\text { 35/2014 } \\
\text { concerning } \\
\text { Amendments } \\
\text { to Law no. } \\
\text { 23/2002 } \\
\text { Law no. } \\
8 / 2016 \\
\text { concerning } \\
\text { Persons with } \\
\text { Disabilities } \\
\text { Law no. } \\
39 / 1999 \text { on } \\
\text { Human } \\
\text { Rights }\end{array}$ & $\begin{array}{l}\text { Article } 28 \text { Letters } \mathrm{H} \\
\text { and I of the } 1945 \\
\text { Constitution } \\
\text { Law no. 20/2003 on } \\
\text { the National } \\
\text { Education System } \\
\text { Law no. 23/2002 } \\
\text { concerning Child } \\
\text { Protection jo. Law } \\
\text { no. 35/2014 } \\
\text { concerning } \\
\text { Amendments to Law } \\
\text { no. 23/2002 } \\
\text { Law no. } 8 / 2016 \\
\text { concerning Persons } \\
\text { with Disabilities } \\
\text { Law no. 39/1999 on } \\
\text { Human Rights }\end{array}$ \\
\hline Right to Health & $\begin{array}{l}\text { Article } 34 \\
\text { paragraphs } \\
(2) \text { and (3) of } \\
\text { the } 1945 \\
\text { Constitution } \\
\text { Law no. } \\
36 / 2009 \text { on } \\
\text { Health }\end{array}$ & $\begin{array}{l}\text { Persons with } \\
\text { disabilities are still } \\
\text { considered/equated } \\
\text { with sick people. } \\
\text { Denial and reduction } \\
\text { of health services for }\end{array}$ \\
\hline
\end{tabular}




\begin{tabular}{|c|c|c|}
\hline & $\begin{array}{l}\text { Law no. } \\
\text { 8/2016 } \\
\text { concerning } \\
\text { Persons with } \\
\text { Disabilities } \\
\text { Law no. } \\
39 / 1999 \text { on } \\
\text { Human } \\
\text { Rights }\end{array}$ & $\begin{array}{l}\text { Persons with } \\
\text { Disabilities. } \\
\text { Lack of care for } \\
\text { health workers }\end{array}$ \\
\hline $\begin{array}{l}\text { Rights to Public } \\
\text { Facilities, } \\
\text { Buildings, and } \\
\text { Transportation }\end{array}$ & $\begin{array}{l}\text { Law no. } \\
22 / 2009 \text { on } \\
\text { LLAJ } \\
\text { Law no. } \\
28 / 2002 \text { on } \\
\text { Buildings } \\
\text { Law no. } \\
39 / 1999 \text { on } \\
\text { Human } \\
\text { Rights } \\
\text { Law no. } \\
8 / 2016 \\
\text { concerning } \\
\text { Persons with } \\
\text { Disabilities }\end{array}$ & $\begin{array}{l}\text { Law no. } 22 / 2009 \text { on } \\
\text { LLAJ } \\
\text { Law no. 28/2002 on } \\
\text { Buildings } \\
\text { Law no. } 39 / 1999 \text { on } \\
\text { Human Rights } \\
\text { Law no. 8/2016 } \\
\text { concerning Persons } \\
\text { with Disabilities }\end{array}$ \\
\hline Right to Work & $\begin{array}{l}\text { Article 28D } \\
\text { paragraph (2) } \\
\text { of the 1945 } \\
\text { Constitution } \\
\text { Law no. } \\
\text { 13/2003 on } \\
\text { Employment } \\
\text { Law no. } \\
39 / 1999 \text { on } \\
\text { Human } \\
\text { Rights } \\
\text { Law no. } \\
8 / 2016 \\
\text { concerning } \\
\text { Persons with } \\
\text { Disabilities }\end{array}$ & $\begin{array}{l}\text { Discrimination in } \\
\text { terms of recruitment, } \\
\text { assessment, and } \\
\text { career path of } \\
\text { workers with } \\
\text { disabilities. } \\
\text { Entrepreneurs are not } \\
\text { oriented towards } \\
\text { persons with } \\
\text { disabilities, because } \\
\text { they are considered } \\
\text { uneconomical. } \\
\text { The understanding of } \\
\text { entrepreneurs and } \\
\text { government officials } \\
\text { regarding the } 1 \% \\
\text { quota as an obligation } \\
\text { is very minimal. }\end{array}$ \\
\hline $\begin{array}{l}\text { Right to a } \\
\text { Decent Standard } \\
\text { of Living and } \\
\text { Social } \\
\text { Protection }\end{array}$ & $\begin{array}{l}\text { Article } 27 \\
\text { paragraph (2) } \\
\text { and Article } \\
28 \mathrm{H} \\
\text { paragraph (1) } \\
\text { of the } 1945 \\
\text { Constitution } \\
\text { Law no. } \\
11 / 2009 \text { on } \\
\text { Social } \\
\text { Welfare } \\
\text { Law no. } \\
40 / 2009 \text { on } \\
\text { Social } \\
\text { Security } \\
\text { System } \\
\text { Law no. } \\
39 / 1999 \text { on } \\
\text { Human } \\
\text { Rights } \\
\text { Law no. } \\
\text { 8/2016 } \\
\text { concerning } \\
\text { Persons with } \\
\text { Disabilities }\end{array}$ & $\begin{array}{l}\text { Persons with } \\
\text { disabilities do not } \\
\text { receive } \\
\text { comprehensive data } \\
\text { on social security } \\
\text { recipients. } \\
\text { The Ministry of } \\
\text { Health has not made } \\
\text { people with } \\
\text { disabilities an issue } \\
\text { that must be } \\
\text { addressed early on. } \\
\text { The Economic } \\
\text { Empowerment } \\
\text { Program disbursed by } \\
\text { the Coordinating } \\
\text { Minister for People's } \\
\text { Welfare and the } \\
\text { Ministry of } \\
\text { Cooperatives and } \\
\text { SMEs does not }\end{array}$ \\
\hline
\end{tabular}

\begin{tabular}{|c|c|c|}
\hline & & $\begin{array}{l}\text { empower persons } \\
\text { with disabilities. }\end{array}$ \\
\hline $\begin{array}{l}\text { Right to } \\
\text { Information and } \\
\text { Communication }\end{array}$ & $\begin{array}{l}\text { Article } 28 \mathrm{~F} \text { of } \\
\text { the } 1945 \\
\text { Constitution } \\
\text { Law no. } \\
14 / 2008 \text { on } \\
\text { Public } \\
\text { Information } \\
\text { Disclosure }\end{array}$ & $\begin{array}{l}\text { The limited } \\
\text { information can be } \\
\text { accessed by the deaf } \\
\text { and blind at various } \\
\text { public service } \\
\text { facilities such as } \\
\text { airports, stations, } \\
\text { hospitals, places of } \\
\text { worship, etc. } \\
\text { There has been no } \\
\text { attention from the } \\
\text { government, Cq } \\
\text { Menkominfo, in } \\
\text { providing/facilitating } \\
\text { the use of sign } \\
\text { language and braille } \\
\text { in public dialogue } \\
\text { forums, for example, } \\
\text { presidential debates } \\
\text { in elections. }\end{array}$ \\
\hline $\begin{array}{l}\text { Right to } \\
\text { Political } \\
\text { Participation }\end{array}$ & $\begin{array}{l}\text { Article 28H } \\
\text { paragraph (2) } \\
\text { and Article } \\
\text { 28I paragraph } \\
\text { (2) of the } \\
1945 \\
\text { Constitution } \\
\text { Law no. } \\
8 / 2015 \\
\text { concerning } \\
\text { Amendments } \\
\text { to Law No. } \\
1 / 2015 \\
\text { concerning } \\
\text { Perppu No. } \\
1 / 2014 \\
\text { concerning } \\
\text { the Election } \\
\text { of Governors, } \\
\text { Regents, and } \\
\text { Mayors to } \\
\text { become Law } \\
\text { jo. Law no. } \\
10 / 2016 \\
\text { Law no. } \\
10 / 2008 \\
\text { concerning } \\
\text { General } \\
\text { Election jo. } \\
\text { Law no. } \\
42.2008 \\
\text { concerning } \\
\text { Presidential } \\
\text { and Vice- } \\
\text { Presidential } \\
\text { Elections } \\
\text { Law no. } \\
12 / 2005 \text { on } \\
\text { Ratification } \\
\text { of the } \\
\text { Convention } \\
\text { on Civil and } \\
\text { Political } \\
\text { Rights } \\
\end{array}$ & $\begin{array}{l}\text { Discrimination in } \\
\text { data collection as } \\
\text { voters } \\
\text { There is no media } \\
\text { interpreter for the } \\
\text { deaf } \\
\text { There is no check } \\
\text { tool yet } \\
\text { There are still many } \\
\text { Prop/District/City } \\
\text { KPU officers, } \\
\text { PPK.PPS who do not } \\
\text { understand the } \\
\text { importance of access } \\
\text { elections for Persons } \\
\text { with Disabilities. } \\
\text { There is no legal } \\
\text { sanction from } \\
\text { election supervisors } \\
\text { to election organizers } \\
\text { regarding the } \\
\text { unavailability of } \\
\text { access to election } \\
\text { facilities and } \\
\text { infrastructure }\end{array}$ \\
\hline
\end{tabular}


In the following, the author will present a study of the implementation of laws and regulations that negate the constitutional rights of persons with disabilities in tabular form [19].

Convention On The Rights Of Persons With Disabilities (Convention on the Rights of Persons with Disabilities). Orientation of legal arrangements for the protection of persons with disabilities is carried out with the aims and objectives:

- protect, promote and ensure the equality of fundamental rights and freedoms for persons with disabilities, as well as respect for the dignity of persons with disabilities as an inseparable part.

- have respect for their mental and physical integrity on an equal basis with others. This includes the right to social protection and services in the context of independence.

- increase awareness of the whole community about persons with disabilities in maintaining respect for the rights and dignity of persons with disabilities.

- fight against stereotypes, prejudices, and harmful practices of persons with disabilities in all areas of life.

- promote acceptance of the rights of people with disabilities.

- promote positive perceptions and increase social awareness of persons with disabilities.

- increase the recognition of skills, qualities, and abilities of people with disabilities, and their contribution to the workplace and the labor market.

- ensure people with disabilities have equal access to the physical environment, transportation, information, and communication, including information and communication technology and systems, as well as other facilities and services open or available to the public, including the elimination of barriers to buildings, roads, transportation facilities, and other indoor and outdoor facilities, including schools, housing, medical facilities, and workplaces.

- promote physical, cognitive, and psychological recovery and social rehabilitation and reintegration of persons with disabilities.

- to ensure that persons with disabilities are not excluded from the general education system on grounds of disability.

- provide persons with disabilities the same quality and standard of services that others receive.
- prohibit discrimination based on disability in all forms of employment, including conditions of recruitment, acceptance, and employment, an extension of employment, career development, and safe and healthy working conditions, an extension of employment, career development, and safe and healthy working conditions.

The protection of persons with disabilities must contain the following substances: The principles and objectives of the protection of persons with disabilities are based on faith and devotion to God Almighty, benefits, kinship, fairness and equity, balance, harmony, and harmony in life, law, independence, science and technology, Duties and authorities of local governments, namely setting policies; establish criteria, standards, procedures, and requirements, provide awards, develop and strengthen cooperation with various parties, conduct campaigns, and socialization in the context of protecting persons with disabilities.

The rights and obligations of persons with disabilities in all aspects of life. Equality of opportunity for all persons with disabilities in all aspects of life and livelihood as well as recognition and respect of others for it. Equality of opportunity covers the fields of Education, Job Opportunities, Social Life, and Health Services. Accessibility regulates the availability of accessibility for persons with disabilities in the utilization and use of public facilities and infrastructure as well as the environment and public transportation facilities. Rehabilitation regulates the resettlement and development of physical, mental, and social abilities of persons with disabilities which includes medical rehabilitation, educational rehabilitation, training rehabilitation, and social rehabilitation. Social assistance for persons with disabilities is directed at meeting basic living needs, developing businesses in the context of independence, and facilitating business opportunities for persons with disabilities. Maintenance of Social Welfare Levels by providing protection and services so that persons with disabilities can obtain a reasonable standard of living.

Useful and useful information for interests in all aspects of life and livelihood. This includes the obligation for persons with disabilities who walk or cycle to use special signs. The role of the community in the context of participating in utilizing capabilities to realize independence and welfare for persons with disabilities.

Providing incentives to business entities that have made efforts to protect persons with disabilities and awarding parties who have contributed to the implementation of the protection of persons with disabilities. Empowerment of persons with disabilities includes the provision of courses and training. The partnership between the local government and the community, legal entities, and or business entities in the implementation of the protection of persons with disabilities with certain principles. 


\section{B. Fulfillment of the rights of persons with} disabilities in Bandar Lampung with the model of "The State of Law for Welfare" as a Public Service for persons with disabilities.

The theory of the welfare state law is a combination of the concepts of the rule of law and the welfare state [20]. The main focus of the welfare state law is to increase welfare by giving an active role to the state to organize welfare (bestuurzorg), public services, and public order and security to make the welfare state more prosperous. The welfare of certain groups (bonum coetuum speculare) or individuals (bonum privatum) [21]. Jimly Asshiddiqie argues that the idea of a welfare state is the influence of the socialist ideology that developed in the 19th century, which was popular at that time as a symbol of resistance to the capitalistliberalist colonialists. From a legal point of view,

"Law is nothing but the very life of mind kind in organized groups and the condition which make possible peaceful co-existence of masses of individuals and social groups and the corporation for other ends than more existence and propagation" [22].

According to Wilhelm Lunstedt, to achieve Social Welfare, the first thing to know about what drives people who live at a certain level of civilization is to achieve their goals. In Lunsteds' opinion, most humans desire to live and develop it properly.

Looking at the views of people in the field of social welfare [23], it can be concluded that the field of social welfare includes a general spirit to do business with its arguments and the existence of security guarantees, so that it can be proven that legal order must be based on values and beliefs that are not absolute formulas but take into account the changing interests of the people in the changing times, circumstances, and changes in the nation's beliefs [24].

We all realize that so far, society and the government do not care about the rights of persons with disabilities. For example, concerning the right to life. Many still stigmatize 'curse' or 'catastrophe' for those who are physically or mentally disadvantaged. Not infrequently, this kind of view comes from close family [25]. This is an example of not caring about the 'privileges' possessed by persons with disabilities.

People with disabilities also often have an unpleasant fate [26]. Either ostracized, sent to an orphanage, or worst of all, shackled. Even if they still live with their families, their rights, such as inheritance, are sometimes taken away by other family members under the pretext that "they can't take care of it."

The state has a clear obligation to ensure effective legal protection for all persons, including those with disabilities [27]. To replace discriminatory social norms, the state needs to ensure that existing laws are applied, all provisions are complied with, and are understood by all people and state apparatus. And last but not least, persons with disabilities are informed about their right to protection from discrimination, and how to exercise that right. The principle of "reasonable accommodation" states that necessary and appropriate adaptations need to be made so that people with disabilities can enjoy their rights just like the rest of society. Putting them in a separate system would not be appropriate to achieve equality.

The exclusion of people with disabilities makes them vulnerable to violence, neglect, and abuse. Some forms of violence are quite specific to children with disabilities. One example of this is using electric shocks or drugs to alter behavior. Women with disabilities in many countries are subject to forced sterilization or abortion [28].

In the understanding of the welfare state law, the rights of persons with disabilities as constitutional rights are prioritized destinations [29]. In this welfare law state, I will describe the following through Brian Z Tamanaha's theory in tabular form.

TABLE II. The Thickest SubStantive Version [30]

\begin{tabular}{|c|c|c|}
\hline No & Form & Information \\
\hline 1 & Formal Legality & $\begin{array}{l}\text { Looking at the views of people in } \\
\text { the field of social welfare, it can } \\
\text { be concluded that the field of } \\
\text { social welfare includes a general } \\
\text { spirit to do business with its } \\
\text { arguments and the existence of } \\
\text { security guarantees, so that it can } \\
\text { be proven that legal order must be } \\
\text { based on values and beliefs that } \\
\text { are not absolute formulas but take } \\
\text { into account the changing interests } \\
\text { of the people in the changing } \\
\text { times, circumstances, and changes } \\
\text { in the nation's beliefs. }\end{array}$ \\
\hline 2 & $\begin{array}{l}\text { Democracy and } \\
\text { legality }\end{array}$ & $\begin{array}{l}\text { A democratic government in } \\
\text { which laws are certain and fair. } \\
\text { As a procedural mode of } \\
\text { legitimacy, democracy also } \\
\text { contains limitations similar to } \\
\text { formal legality so that it can also } \\
\text { lead to bad practices of } \\
\text { authoritarian power. }\end{array}$ \\
\hline 3 & Individual Rights & $\begin{array}{l}\text { The existence of contracts, } \\
\text { property rights, and personal } \\
\text { autonomy. }\end{array}$ \\
\hline 4 & Social Welfare & $\begin{array}{l}\text { The equality that is fundamental } \\
\text { and essential ensures the welfare } \\
\text { and the maintenance of someone } \\
\text { in the community. }\end{array}$ \\
\hline
\end{tabular}

In the new thinking about democracy, one of the important points is that democracy must give space to the existence of marginal groups in society to be able to articulate their existence in the system and structure of society. Included in the so-called marginal groups are persons with disabilities [31]. The government's important role in changing perceptions is to provide accessibility for various basic interests [32].

The main factor driving the development of the welfare system is the desire of the ruling authorities to 
promote national solidarity. The welfare system is constructed as part of a more general state development process [33]. The role of cooperation between all parties needs to be carried out in realizing the welfare system. Welfare is of course for people with disabilities who need special attention for their life needs. Without complaining about the role of the government, which incidentally is always blamed for its lack of perceived role in the welfare of its people, it is the government's weakness that should be a gap for other communities to support performance and perfect the work of the government [34] in jointly advancing a country that prospers its citizens, The community should protect and respect the existence of persons with disabilities wherever they are, especially in the academic community which is a place for seeding the nation's intellectual cadres [35]. The role of campuses in supporting the fulfillment of the rights of people with disabilities is a forum that needs to be taken into account as an effort to realize the tri dharma of higher education in the field of community service.

Mahmud Pasya from (Indonesian Association of Persons with Disabilities), submitted a willingness to assist campuses in conditioning campus dynamics with special shelters or special disability study centers, as student laboratories to access information and create an inclusive campus [35]. We must recognize that not all people with disabilities are reached by government services. Not all local governments can use APBD funds to support government activities for people with disability. The government and local governments are expected to expand the reach of social utility programs, including The Social Welfare Program for the Severely Disabled (ASPDB) and the Family Empowerment Program for the Severely Disabled [36]. If we understand carefully that individual rights which the writer interprets as constitutional rights of disability, there is a correlation with "Social Welfare" or the state of welfare law [36]. Welfare which is the main priority in the understanding of the welfare state law places "social interest" as "substantial central" and should not be reduced to "marginal residual". In the context of recognizing the constitutional rights of people with disabilities, this is justified by the understanding of the welfare state law [37]. The meaning of the notion of the welfare state will be seen and welfare guarantees will be realized by good regulation of public services [38].

In "The Modest Objectivist View of Human Rights," the claim that human rights become constitutional rights is made. It is more specifically called the right to demand. When these rights are embodied in every legal event, it will help everyone obtain a decent life more easily [39]. As the author has detailed, in table 1 it can be seen that at the level of implementing the rules regarding the rights of persons with disabilities, there are still many rights of persons with disabilities as constitutional rights which are still neglected [40]. Concerning the provision of public services following Article 4 letters c, g, and j of Law No. 25 of 2009 on public services that the implementation of public services is based on equality, non-discriminatory and provides special facilities and treatments for vulnerable groups [41]. The mainstreaming of these provisions has not been fulfilled properly. Human rights are often like scribbles without meaning because they are not universal. If we turn to the universalist perspective, that human rights should be treated as "human beings" [42]. A perspective that focuses on human rights gives birth to government policy products that are not charity-based. This paradigm shift will be illustrated in the diagram below [43]. Indeed, if we refer to the perspective of totalitarianism that human rights must be considered as "humans" [42].

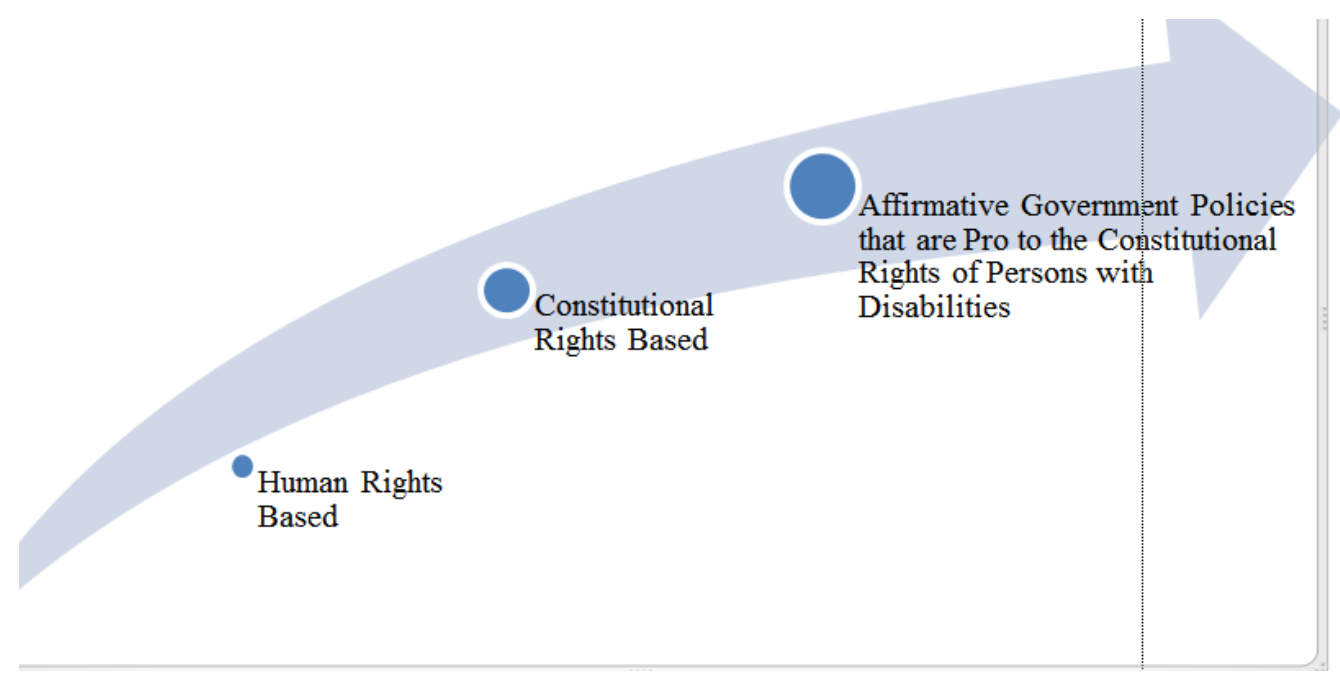

Fig. 1. Transition to the Constitutional Rights of Persons with Disabilities

The shift from "charity-based" to constitutional rights-based will result in an affirmative government policy towards the protection of the constitutional rights of people with disabilities [44]. By carrying out these 
transitional actions, the paper will briefly describe several things that can be an instrument to protect the constitutional rights of persons with disabilities in tabular form.

TABLE III. THINGS THAT CAN BE AN INSTRUMENT TO PROTECT THE CONSTITUTIONAL RIGHTS OF PERSONS WITH DISABILITIES

\begin{tabular}{|c|l|}
\hline No. & \multicolumn{1}{|c|}{$\begin{array}{c}\text { An instrument for the Protection of Constitutional } \\
\text { Rights } \\
\text { Persons with Disabilities }\end{array}$} \\
\hline 1 & $\begin{array}{l}\text { Policies related to the affirmation that children with } \\
\text { disabilities have the same rights as non-disabled } \\
\text { children to attend public/regular schools (both in the } \\
\text { form of regulations and non-regulation) }\end{array}$ \\
\hline 2 & $\begin{array}{l}\text { The need for strict supervision of the right to education } \\
\text { for persons with disabilities }\end{array}$ \\
\hline 3 & $\begin{array}{l}\text { Early orientation program for health accessibility for } \\
\text { persons with disabilities }\end{array}$ \\
\hline 4 & $\begin{array}{l}\text { The need to change the perspective that "disability" is } \\
\text { not synonymous with "sickness" }\end{array}$ \\
\hline 5 & $\begin{array}{l}\text { The need to improve public facilities with various } \\
\text { procurements for the needs of persons with disabilities }\end{array}$ \\
\hline 6 & $\begin{array}{l}\text { Divergence of the realization of the 1\% quota obligation } \\
\text { of agencies in the world of work for persons with } \\
\text { disabilities }\end{array}$ \\
\hline
\end{tabular}

According to the author, if the instruments contained in the table are realized, everyone's constitutional rights will be fulfilled. If the rights of persons with disabilities are fulfilled, then it is certain that equal rights for persons with disabilities will be realized.

\section{CONCLUSION}

Article 1 point 1 of Law no. 8 of 2016 concerning persons with disabilities, a person with disabilities is any person who, in the long term, experiences physical, intellectual, mental, and/or sensory limitations that interact with the environment, may experience obstacles and difficulties for full and effective participation others citizens on an equal basis. Article 3 letters $a$ and $b$ of the provision state that the implementation and fulfillment of the rights of persons with disabilities are aimed at realizing full and equal respect, promotion, protection, and fulfillment of human rights and basic freedoms for persons with disabilities and guaranteeing efforts to respect, promote, protect and fulfill rights as inherent dignity of persons with disabilities.

The protection and fulfillment of the rights of persons with disabilities as constitutional rights remain a dilemma. At the heart of this problem is the fact that both politicians' and societal outlooks continue to be based on "philanthropy" rather than "human rightsbased" or "constitutional rights". In a society that is polarized towards normalcy, the existence of persons with disabilities is eliminated due to the creation of government policy products that are not pro to the constitutional rights of persons with disabilities. Due to problems like these, it is necessary to change the paradigm for both policymakers and the public that the connotation of "disability" is not synonymous with the connotation of "sick".

\section{REFERENCES}

[1] http://www.kemlu negeri).go.id/Pages/News. 06/06/12

[2] Fanny Priscyllia.2016. Kajian Hukum Terhadap Fasilitas Pelayanan Publik Bagi Penyandang Disabilitas . Lex Crimen Vol. V/No. 3. Hlm 111

[3] Zulfah Latuconsina, Januari 2014 "Afirmasi Kebijakan Pemerintah dalam Fasilitasi Kerja bagi Penyandang Disabilitas", dalam Jurnal Unnesa, Volume 9, Nomor 2, P. 204.

[4] Undang-Undang Nomor 39 tahun 1999 tentang Hak Asasi Manusia.

[5] Laica Marzuki, Agustus 2011 "Konstitusionalisme dan Hak Asasi Manusia", dalam Jurnal Konstitusi,Volume 8, Nomor 4, P. 480.

[6] Jessica M. F. Huges "Constructing a United Disability Community: The National Council on Disability's Discourse of Unity in the Deliberative System around Disability Rights," Journal of Public Deliberation: Vol. 12: Iss. 1, Article 8, p.3.

[7] Slamet Thohari. 2014. Pandangan Disabilitas dan Aksesibilitas Fasilitas Publik bagi Penyandang Disabilitas di Kota Malang. Indonesian Journal of Disability Studies. Vol. 1 Issue $1 \mathrm{Hlm}$. 27-37

[8] James H. Rimmer, Ph.D. 2005.The Conspicuous Absence of People With Disabilities in Public Fitness and Recreation Facilities: Lack of Interest or Lack of Access?. American Journal of Health Promotion. Vol. 19, No. 5

[9] Sesya Dias Mumpuni, Arif Zainudin. 2017. Aksesbilitas Penyandang Disabilitas Dalam Pelayanan Publik Di Kabupaten Tegal. Jurnal Komunikasi Pendidikan, Vol 1, No 2, Hlm 134-135

[10] Intan Nadia, "Persoalan Disabilitas", diakses dari http://www.kompasiana.com/intanintanan/persoalandisabilitas_552e5c726ea8341d548b45b3, Pada tanggal 29 Oktober 2016, Pukul 22:09 WIB.

[11] The current paradigm towards persons with disabilities is still limited to pity. So that the products of government policies including the provision of facilities and so on are still very minimal. The existence of persons with disabilities is often eroded by the flow of normality.

[12] Tim Penulis, "Kerangka Hukum Disabilitas di Indonesia: Menuju Indonesia Ramah Disabilitas", (Jakarta: Pusat Studi Hukum dan Kebijakan Indonesia, 2015), hlm. 10.

[13] Arthur W. Blaser, "Making Rights a Reality? Disability Rights Activists and Legal Mobilization by Lisa Vanhala", (Cambridge, UK, and New York: Cambridge University Press, 2011), p. 511

[14] Stuart Cumella. 2018.New Public Management and Public Services for People With an Intellectual Disability: A Review of the Implementation of Valuing People in England. Journal of Policy and Practice in Intellectual Disabilities. Volume 5 Number 3 pp 182-183.

[15] Atep Adya Barata. (2003). Dasar-dasar Pelayanan Prima. Gramedia: Jakarta. Hlm 30

[16] Budiyono, Rudy, Konstitusi dan HAM, Bandar Lampung, PKKPU, 2015, hlm. 53

[17] Petra W. B. Prakosa. Dimensi Sosial Disabilitas Mental di Komunitas Semin, Yogyakarta. Sebuah Pendekatan Representasi Sosial. Fakultas Psikologi Universitas Gadjah Mada. Jurnal Psikologi Volume 32, No. 2, Hlm. 68

[18] Heppy Sebayang, “Advokasi Organisasi Penyandang Disabilitas", (Jakarta: PPUA Penca,2012), hlm. 46. 
[19] Suryadi. 2017. The Availability of Transportation for Disabled Workers in Java and Bali Islands. Warta Penelitian Perhubungan, Volume 29, Nomor 2. Hlm 479.

[20] Triana Sofiani, "Hak Konstitusional Buruh Perempuan dalam Bingkai Negara Hukum Kesejahteraan Di Indonesia”, dalam artikel Muwazah, Vol. 6 No. 1, hlm. 107.

[21] Daniel F. Piar, A Welfare State of Civil Rights: The Triumph of the Therapeutic in American Constitutional Law, 16 Wm. \& $\begin{array}{lllll}\text { Mary Bill Rts. } & \text { J. } & 649 & \text { (2008), }\end{array}$ http://scholarship.law.wm.edu/wmborj/vol16/iss3/2, p. 651.

[22] Soemardi, Teori Umum Hukum dan Negara : Dasar-Dasar Ilmu Hukum Normatif Sebagai Ilmu Hukum DeskriptifEmpirik, Bee Media Indonesia, Bandung, 2010, hlm 9.

[23] Spencer E. Cahill, Robin Eggleston.2016. Reconsidering The Stigma Of Physical Disability: Wheelchair Use And Public Kindness. Sociological Quarterly Vol. 36/No. 4/1995. P. 683

[24] http://repository.unpas.ac.id/14223/5/7\%20BAB\%20II.pdf, dikutip pada Jum'at 27 Oktober 2020, 20.00 WIB.

[25] https://www.rappler.com/indonesia/126291-dpr-sahkan-uupenyandang-disabilitas, dikutip pad 27 Oktober 2020, Pukul 22.00 WIB.

[26] M. Rezaul Islam. 2015. Rights of the People with Disabilities and Social Exclusion in Malaysia. International Journal of Social Science and Humanity, Vol. 5, No. 2, Hlm. 175

[27] Carlo Francescutti, Lucilla Frattura, Raffaella Troiano, Francesco Gongolo, Andrea Martinuzzi, Marina Sala, Paolo Meucci, Alberto Raggi, Emanuela Russo, Mara Buffoni, Giovanna Gorini, Mario Conclave, Agostino Petrangeli, Alessandro Solipaca \& Matilde Leonardi. 2009towards A Common Disability Assessment Framework: Theoretical And Methodological Issues For Providing Public Services And Benefits Using Icf. Disability and Rehabilitation, 31(S1): S8S15

[28] https://www.unicef.org/indonesia/id/SOWC_Bahasa.pdf, dikutip pada 27 Oktober 2020, pukul 21.00 WIB.

[29] William E. Forbath, Constitutional Welfare Rights: A History, Critique and Reconstruction, 69 Fordham L. Rev. 1821 (2001). Available at: http://ir.lawnet.fordham.edu/flr/vol69/iss5/12, p. 1850 .

[30] Brian Z. Tamanaha, "On The Rule of Law", (Cambridge : University Press, 2004), p.92.

[31] Ummi Zakiyah, Rahmawati Husein. 2016. Pariwisata Ramah Penyandang Disabilitas Studi Ketersediaan Fasilitas Dan
Aksesibilitas Pariwisata Untuk Disabilitas Di Kota Yogyakarta. Jurnal Ilmu Pemerintahan \& Kebijakan Publikvol. 3 No. 3. Hlm 484

[32] http://presidenri.go.id/program-prioritas-2/model-pemenuhanhak-penyandang-disabilitas-kota-solo.html, dikutip Pada 2 Februari 2020, Pukul 14.30 WIB.

[33] https://journal.ugm.ac.id/jkap/article/view/8320/6429, dikutip pada 20 Oktober 2020, Pukul 20.00 WIB.

[34] D. Morin, M. Rivard, A. G. Crocker, C. P. Boursier \& J. Caron. 2013. Public Attitudes Towards Intellectual Disability: A Multidimensional Perspective. Journal of Intellectual Disability Research. Volume 57 Part 3 Pp 285

[35] https://www.kemsos.go.id/berita/kemensos-ajak-masyarakathargai-penyandang-disabilitas, dikutip pada 28 Oktober 2020, Pukul, 21.00 WIB.

[36] https://www.kemsos.go.id/artikel/tinjauan-yuridis-danempiris-pemenuhan-hak-hak-penyandang-disabilitas-berat, dikutip pada 28 Oktober 2020, Pukul 22.00 WIB.

[37] Nilda Mutia, Yanis Rinaldi. 2017. Pelaksanaan Pelayanan Publik Bagi Penyandang Disabilitas Di Kota Banda Aceh. Jim Bidang Hukum Kenegaraan : Vol. 1, No.1 . Hlm 59

[38] Kiser, Larry L. \& Stephen L. Percy. (1980). The Concept of Coproduction and Its Implication for Public Service Delivery. Paper presented at the 1980 Annual Meetings of the American Society for Public Administration, on April 13-16. Indiana University Bloomington.

[39] Allen Buchanan, "Equality and human Rights", dalam Article Politics, Philosophy and Economics (London: Sage Publication Ltd, 2005), p. 71.

[40] Pauline Conroy, "Disability Rights-Justice Delayed", in Article Studies (Dublin: TASC, 2010), p.34.

[41] Pasal 4 UU No. 25 tahun 2009 tentang Pelayanan Publik.

[42] Yudi Latif, "Negara Paripurna; Historis, Rasionalitas, dan Aktualitas Pancasila", (Jakarta: PT Gramedia Pustaka Utama, 2012), hlm. 219

[43] Zulkarnain Ridlwan. 2013. Perlindungan Hak-Hak Konstitusional Penyandang Disabilitas (Rights Of Persons With Disabilities). Fiat Justisia Jurnal Ilmu Hukum Volume 7 No. 2. Hlm 236 